\author{
Alicja PIHAN-KIJASOWA \\ Uniwersytet im. Adama Mickiewicza, Poznań \\ apki@amu.edu.pl \\ http://orcid.org/0000-0002-7104-8154
}

\title{
STEREOTYP KAPLANA WPISANY W XVII-WIECZNE KAZANIA POGRZEBOWE
}

W XVII wieku jedną z częstszych form wypowiedzi publicznej były kazania (Sokołowska 1990). Wygłaszane były podczas nabożeństw do wiernych i były formą nauczania i przekazywania treści religijnych bądź, jako homilie, objaśniania tekstu biblijnego. W interesującym nas okresie powstawały też liczne kazania okolicznościowe na uroczystości religijne i świeckie - stanowiły ważny element oprawy tych uroczystości (Szostek 1990: 320; Skwara 2009: 320), jak np. kazania na wjazd do miasta ważnej osoby, kazania uświetniające wydarzenia państwowe, polityczne, ale też mniejszej rangi, jak choćby wydarzenia miejskie, kazania z okazji ślubu, pogrzebu itd. Do naszych czasów dotrwało ich wiele; zostały przez XVII-wiecznych wydawców opublikowane jako niewielkie (kilkunasto- lub kilkudziesięciostronicowe) druki. Poza publikacją pojedynczych tekstów ukazało się też wiele zbiorów różnego typu kazań, które nie tylko prezentowały sztukę kaznodziejską konkretnego duchownego, lecz stanowiły też pomoc w konstruowaniu mowy dla innych kaznodziejów. Ponadto na potrzeby nauczania szkolnego, w ramach nauki stylu retorycznego, powstawały (poza uznanymi antycznymi) nowe opracowania retoryki, drukowane i rękopiśmienne, które odpowiadały zapotrzebowaniu społecznemu, przede wszystkim bujnemu życiu polityczno-publicznemu szlachty polskiej, a także rozwojowi krasomówstwa we wszystkich kościołach, katolickich i protestanckich. Ówczesne retoryki przybierały postać kompendiów przydatnej oratorom/kaznodziejom wiedzy erudycyjnej, literackiej i dotyczącej konkretów życia społecz- 
nego ${ }^{1}$. Zawierały nie tylko wzorcowe teksty kazań, ale też zbiory cytatów, związków frazeologicznych, rozmaitych formuł, fragmenty rzeczywistych i fikcyjnych mów, listów itp. (Otwinowska 1990: 719). Kaznodzieja dysponował więc konkretną pomocą przy konstruowaniu tekstu.

Wśród zachowanych XVII-wiecznych kazań wyróżniają się i na uwagę zasługują kazania pogrzebowe. Ile ich wówczas powstało i ile zostało opublikowanych, nie wiemy. Zachowanych do naszych czasów w całości bądź przynajmniej znanych ze wzmianek w źródłach Marek Skwara, autor bibliografii XVII-wiecznych druków funeralnych, zarejestrował około 600 (Skwara 2009). Pamiętać jednak należy, że spora część ówczesnych druków może być dzisiaj nieznana. Historycy drukarstwa szacują, że może to być nawet około $50 \%$ w stosunku do produkcji znanej (Topolska 1984: 118-121). Ale i te zachowane kazania stanowią kolekcję obfitą, dającą dobrą podstawę do różnorakich badań naukowych (historycznych, genealogicznych, kulturoznawczych, socjologicznych, literackich, językoznawczych). Dla badań historycznojęzykowych, podobnie jak dla np. literackich, ważne jest usytuowanie kazania na płaszczyźnie genologicznej. Za teoretykami zagadnienia włączymy tekst kazania w ciąg tekstów użytkowych o stosunkowo trwale uregulowanym wzorcu, ale przy indywidualnym charakterze wypowiedzi (w odróżnieniu np. od modlitwy ustalonej) także pewnej dezintegracji tego wzorca z powodu przeobrażeń i nacisku praktyki kaznodziejskiej (Wojtak 1999; Wojtak 2004-2005: 167). Kazanie pogrzebowe jest gatunkiem literatury okolicznościowej pozostającej w związku genetycznym i chronologicznym z wydarzeniem zewnętrznym - z pogrzebem (Michałowska 1990: 420). Narracja skupia się na osobie zmarłej, a sytuacja implikuje określoną postawę mówcy wobec tej osoby. Polega ona na przesadnie wyolbrzymionej pochwale. Jest więc kazanie pogrzebowe utworem panegirycznym (Dziechcińska 1990: 544), realizującym retoryczne zasady laudatio, wyłożone $\mathrm{w}$ traktatach retorycznych. Średniowiecze i wieki następne znały traktat gramatyka Pryscjana (V-VI w.), który w rozdziale De laude (O pochwale) zawarł zasady i reguły chwalenia (Dziechcińska 1990: 544). W części dotyczącej osoby pokazuje, w jakiej kolejności i jakie cechy mają być chwalone:

$1 \mathrm{~W}$ siedemnastowiecznej Polsce w nauczaniu retoryki odwoływano się do zasad wypracowanych $\mathrm{w}$ antyku, ale od XVI w. w Polsce zaczęły powstawać rodzime kompendia retoryczne, jak np. S. Sokołowskiego Partitiones ecclesiasticae, 1589; K. Wijuka Kojałowicza Institutionem Rhetoricarum partes II, 1634 (Szostek 1990: 317-319). 
Po pierwsze, trzeba powiedzieć o przynależności narodowej i państwowej, przedstawić rodowód bohatera, dalej - jego przyjście na świat (mogło być poprzedzone nadprzyrodzonymi znakami i przepowiedniami), następnie wychowanie itd. Odrębna część pochwał powinna dotyczyć «ciała i duszy», a więc takich cech, jak piękność fizyczna, siła, zręczność z jednej strony, a sprawiedliwość, umiarkowanie, dzielność i mądrość - z drugiej. Należy także chwalić profesję bohatera, określając dokładnie, jaką pełnił funkcję społeczną. Najdokładniej zaś omówić trzeba jego czyny. Chwali się także człowieka z powodu «okoliczności zewnętrznych», uwzględniając jego rodzinę, przyjaciół, potomków; czas, w którym żył i wreszcie - rodzaj śmierci. Powyższym treściom pochwały musiała towarzyszyć amplificatio (wyolbrzymienie) (Dziechcińska 1990: 544-545).

W siedemnastowiecznej Polsce, w okresie wzmożonego zainteresowania literaturą panegiryczną, rozwijano refleksję teoretyczną nad istotą pochwały i nad sposobami jej formułowania. Wzorowano się szczególnie na podręczniku Kwintyliana, który pochwałę dzieli na trzy «części chronologiczne».

W części poświęconej czasowi poprzedzającemu narodzenie mówca powinien zastosować argumenty z trzech «miejsc»: patria (ojczyzna), parentes (rodzice i przodkowie), responsis vel auguariis (wyrocznie lub przepowiednie). Chwaląc życie zmarłego, orator wykorzystuje argumenty z następujących «miejsc»: ex animo (z cech charakteru) et corpore (z cech fizycznych) et extra positis (z zewnętrznych okoliczności). W trzeciej «części chronologicznej» (czas po śmierci) Kwintylian wskazuje na pomniki geniuszu (ingeniorum monumenta), które oparły się próbie czasu. Niektórzy ludzie cieszyli się większą sławą u następnych pokoleń niż wśród swoich współczesnych (Skwara 2008: LXXXVIII).

I właśnie ten: „Skodyfikowany przez Kwintyliana trójdzielny schemat pochwały został przyjęty przez autorów wielu nowożytnych podręczników retoryki [...] oddziałał także na kształt budowy i kreację pochwały w funeralnej homiletyce" (Skwara 2008: LXXXVIII).

Wcześniejsze moje analizy XVII-wiecznych kazań pogrzebowych, głoszonych na pogrzebach mężczyzn (Pihan-Kijasowa 2013) i kobiet (Pihan-Kijasowa 2016), wykazały skrupulatne realizowanie przez kaznodziejów wskazanego wyżej trójdzielnego schematu pochwały. I choć, oczywiście, różnice jednostkowe są wyraźne, to polegają one głównie na różnym rozłożeniu akcentów, na przywoływaniu różnych argumentów wypełniających elementy schematu, nie zaś na eliminacji któregoś z nich. Nieco inaczej rzecz się ma w odniesieniu do kazań na pogrzebach 
osób duchownych. W tym przypadku obserwujemy nieco inne podejście do zaleceń budowy pogrzebowej laudacji. Pierwszy element schematu, czyli czas poprzedzający narodzenie zmarłego, pojawia się nieobligatoryjnie. Wobec tego w większości kazań brakuje argumentów odnoszących się do rodu, z którego wywodził się zmarły, jego starożytności i wielkości, zasług dla ojczyzny i Kościoła. Jeśli incydentalnie się pojawiają, to są na ogół zredukowane do argumentów najistotniejszych dla stanu kapłańskiego osoby zmarłej. Przywoływana więc jest bogobojność i pobożność rodziców zmarłego, rzadziej innych przedstawicieli rodu, jak np. ksiądz Adam Makowski na pogrzebie ojca Fabiana Birkowskiego mówił: Są poniekąd cni i bogoboyni zmarłego rodźicy (MakA B); Aleć ia wierzę, że y ći pobożni Kapłana tego rodźicy, nielada poćiechę mieli (MakA C) czy Wojciech Pigłowski na pogrzebie księdza Zygmunta Cieleckiego, proboszcza poznańskiego i kanonika gnieźnieńskiego, krakowskiego i płockiego przywołuje postać ważnej w familii Cieleckich osoby - biskupa płockiego: Wielki był [...] niebojzczyk ś. Pamięći I.X. Hieronim Cielecki, Bifkup Płocki, ktory [...] piękna pobożnośći Jwoiey roznymi fundacyami zoftawił pamiatke (PigK Bv). Z rzadka pojawia się prosta informacja o starożytności rodu, jak w kazaniu Franciszka Wierusza na po-

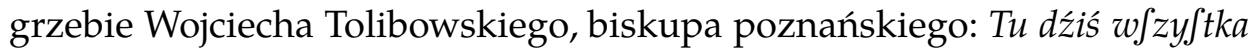
Dobrzyńfka Zięmia y Jaśnie Wielmożne z Starożytnem Domem Ich Mćiow PP Tholibowfkich złaczone Familie (Wier B2) czy w kazaniu Marcina Protfica na pogrzebie Stanisława Sarnowskiego, biskupa kujawskiego i pomorskiego wspomniana została: Starożytna Familia Mośćiow Panow SARNOWSKICH (Prot Av). Incydentalnie kaznodzieja podkreśla starożytność rodu, odwołując się do świadectwa źródła historycznego. Zabieg taki zastosował Wojciech Pigłowski: Co do dawnośći: znayduię ia z Herbem Ich-

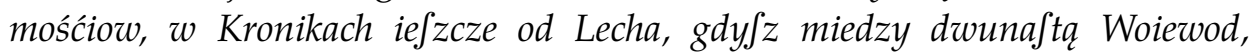
ktorzy po Lechu Pańftwem rządźili, twierdza bydź iednego tego Herbu Zaremba (PigK Bv). Nieco częściej kaznodzieje przywołują funkcje i godności (świeckie i kościelne), jakie były udziałem familii zmarłego, jak np. w kazaniu Jakuba Olszewskiego czytamy o przodkach i braciach zmarłego księdza Karola Jana Białozora: Stryiow miał ludźi zacnych urzędnikow: Marfzałek W.K.L. Doroftayfki, y Ich Mść PP. Rayfcy w Koronie: Braćia rodzeni Urzędnicy wielcy w powiećie Upitfkim: Marfzałek ieden, a drugi Podkomorzy (OlszB B2).

Inny element laudacji, pojawiający się, choć z rzadka, tylko w kazaniach na pogrzebach osób świeckich, czyli wyrocznie i przepowiednie 
poprzedzające narodzenie osoby zmarłej, $w$ analizowanych kazaniach na pogrzebach duchownych pojawił się tylko raz jako proroczy sen matki. Ludwik Skrobkowic na pogrzebie Jakuba Zadzika, biskupa krakowskiego, dowodził, że: Rodźićielce iego przyśniło Jię, że miafto dźiéciećía powiła Jtońce (SkrobK Dv).

Jeszcze uboższy jest trzeci element schematu laudacyjnego - wskazanie tzw. pomników geniuszu, które oparły się próbie czasu. Ponieważ pogrzeb odbywał się wkrótce po śmierci osoby, więc owe pomniki geniuszu nie miały pewnie jeszcze możliwości się objawić. Kaznodzieje ograniczają się więc do proroctw typu: Wiecznie żyiefz, bo iuż przybrało do Swego

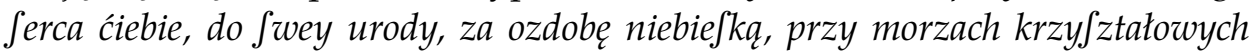
reziduiaca Oblubienica (Mros B2).

Podstawą więc laudacji na pogrzebach osób duchownych jest rozbudowany drugi element schematu, odnoszący się bezpośrednio do zmarłego, do jego życia, czynów, wykształcenia, posługi kapłańskiej, cech charakteru. Z zalecanych w podręcznikach retoryki składowych tej części laudacji, na pogrzebach osób duchownych nie pojawiają się natomiast argumenty z zakresu cech fizycznych osoby zmarlej, które w ogóle w XVII-wiecznych kazaniach głoszonych na pogrzebach tak mężczyzn, jak kobiet są zaledwie incydentalne (Pihan-Kijasowa 2013; Pihan-Kijasowa 2016).

Podkreślmy, że zachowane kazania na pogrzeby osób duchownych to wyłącznie kazania pochwalne, nie znamy żadnych kazań tzw. ganiących (nie zachowały się?). Wobec tego pochwalna postawa kaznodziei wyraża się poprzez przywoływanie wyłącznie cnót osoby zmarłej. Układają się one w wiązki sądów zdających sprawę z cech podmiotu - tu: zmarłego duchownego, które za Anną Wierzbicką nazwać możemy fasetami. Tak rozumiane fasety stanowią zhierarchizowaną strukturę, w której jednym jej elementom przypisuje się wyższą rangę (przy uwzględnieniu wielu tekstów - występowanie w każdym tekście $\mathrm{z}$ dużą częstością), innym niższą (w tekstach przywoływane są rzadziej). Tak więc kształtowanie obrazu osoby zmarłej poprzez ujęcie jej własności w określonych fasetach $\mathrm{z}$ uwzględnieniem rangi danej fasety $\mathrm{w}$ strukturze i zgodnie $\mathrm{z}$ wymogami określonego punktu widzenia jest podstawą profilowania podmiotowego pojęcia (Bartmiński, Niebrzegowska 1998: 212).

Dla przedstawianego problemu wyróżniam kilka faset, z których najistotniejsze to: 
FASETA I - WIARA OSOBY ZMARŁEJ

W obrazie osoby duchownej najwyższą rangę zajmuje atrybut pobożności, wyrażany leksemami i związkami wyrazowymi: pobożny $\dot{z} y$ wot (Patrzćie na gefta pobożnego żywota iego (MakA Dv), pobożność, na-

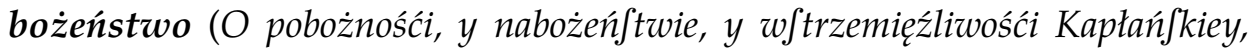

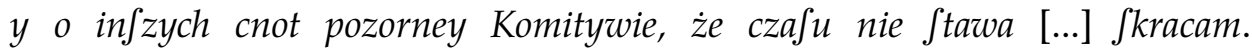
WolsS [D4v]), świątobliwy (Aza niewiećie, że Bifkup, y Primas, a barzo świątobliwy, wchodźi dźiś do grobu. Widz [A4]) i świątobliwie jako człon nominacji zmarłego (dla pochwały świątobliwie zmarłego Iaśnie Oświeconego J.M.X. PIOTRA GEMBICKIEGO. KochW [A4]), pobożny i święty (przy tym oftatnim Akćie pogrzebowym, temu pobożnemu, a iż tak rzekę, Swiętemu Bifkupowi, to zaśpiewał), związki wyrazowe: przeciw Kościołowi mitość (Affekt ten świadczyć będa wjzytkie Krakowfkie Kośćioty [...] iego przećiw Kośćiołowi miłość (Mros $\mathrm{C} 2 \mathrm{v}$ ), wszytko serce, wszytkie afekty oddawat Bo-

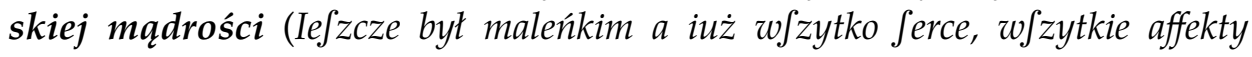
oddawał Bofkiey madrośći. Mros [B4v]).

W opisie głębokiej, gorącej wiary zmarłego istotną rolę odgrywają obrazy stosowanych przez niego praktyk religijnych, także tych o charakterze dewocyjnym. W tym kontekście pojawiają się określenia jednoi wielowyrazowe, niejednokrotnie $\mathrm{z}$ dużą szczegółowością opisujące owe praktyki, jak np.: kaptańskie odprawowat pacierze (Zkąd tak pilny zba-

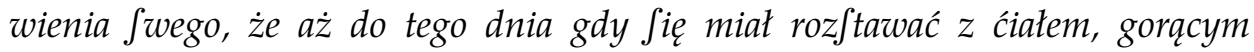
iednoczyt Jię affektem, z Bogiem Kapłańfkie odprawuiąc paćierze. Mros [C4v]), mszy stuchat, spowiadat się, Najświętszego Sakramentu zażywat (Oćiec

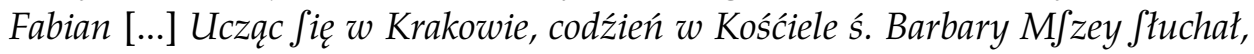
y tam Się naczęśćiey Spowiadat, y Naświęt zego Sakramentu zażywat. MakA B3), Pismo Święte czytat z poważnym rozmysłem (Birk C2), gorące modlitwy czynit (Birk D), czy opisy praktyk dewocyjnych, jak np.: klęczeć na gołej ziemi (Widz C2v), leżeć często krzyżem na ziemi (Widz C2v-[C3]), w worze, boso dyscypliny czyni (Widz [C3]). Nierzadkie też są drastyczne i szczegółowe opisy praktyk dewocyjnych, jak to przedstawił Marcin Protfic w odniesieniu do księdza Stanisława Sarnowskiego: Były iefzcze tego pobożnie zmarłego, Iaśnie Wielmożnego Iego Mośći X. Biskupa najzego manus verfatiles; bo nie raz ćiało iego, dobrze do krwi Samey, włośiennemi i innemi

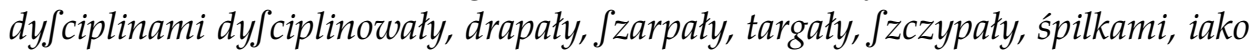

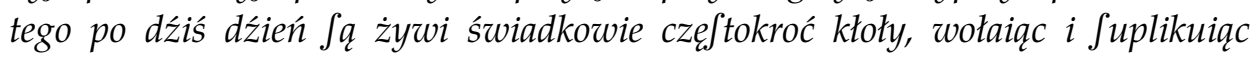
do Boga (Prot [B4]). Także ksiądz Fabian Birkowski plastycznie opisuje 
praktyki dewocyjne stosowane przez Piotra Skargę: Nim poczynat Jkracać Tomy Baroniufzowe, przed kożdym, dwadźieśćia pięć difcyplin, abo dwadźieśćia (maiac na ten czas iuż lat 65.) czynit. Przed pifmem o czterech of tatecznych rzeczach każdego człowieka, dźieśięć difcyplin. Przed kazaniem ktore z pilnośćiq miat wola pifać, z ofobna pięć difcyplin [...] Tak on namillzy Starzec [...] z ćiatem fwoim poczynał iako z nieprzyiaćielem, przykazuiac mu poftufzeńftwo duchowi, przez gefte difcypliny, a P. Boga blagaiac umartwieniem (Birk [C4]-[C4v]).

\section{FASETA II - DLA KOŚCIOŁA}

Skupiają się tu te atrybuty zmarłego, które pokazują jego szczególne zasługi dla Kościoła, ale też dla wspólnoty skupionej wokół Kościoła. $\mathrm{Z}$ pewnością najwyższą rangę $\mathrm{w}$ niematerialnych zasługach stanowi udział zmarłego w konwersji innowierców na katolicyzm. Wielu kapłanów, którym poświęcone są kazania, według opinii kaznodziejów przyczyniło się do zmiany wiary innowierców. I tak np. ksiądz Marcin Widziewicz o biskupie wileńskim Benedykcie Woynie powiada: Wielmożnego Pana Iego M.P. Staniftawa Kifzkę Starego [...] z Kalwińfkiey Sekty y Zboru, do Wiary prawdźiwey, y Kośćioła ś. Katholickiego Jzcześlizwie poćiqgną (Widz D3). Ksiądz Fabian Birkowski w odniesieniu do księdza Piotra Skargi używa prostej frazy heretyki nawracat: Czegoż na ten czas nie czynit nafz X. Piotra Skarga [...] Heretyki nawracat, miedzy ktoremi iednę Woiewodźina

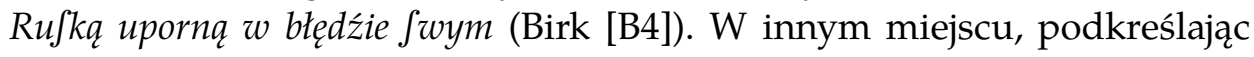
zasługi Piotra Skargi dla Kościoła, podkreśla: gdy obaczył Koronę Poljkg Heretykami zefzpecona, ogniftym kazaniem Swym wypalat $z$ nich kacerftwa Kalwińfkie, Aryańfkie, odfzczepieńfkie Greckie, ktorych potym do kośćiota Katholickigo prowadżił (Birk C2). Miał też Skarga swój udział w chrystianizacji Żydów: Kto nie widźiat gdy Roku P. 1592, na zamku Krakowjkim w kośćiele, Iośka Peletowica Zyda do chrztu ś. prowadźit (Birk C3).

Najczęściej jednak i najobficiej kaznodzieje wskazują materialne zasługi zmarłego kapłana dla Kościoła, a więc liczne i bogate fundacje, darowizny, datki, w tym także, jak to można określić, fundacje pośrednie, a więc przekazywane przez inne osoby, ale z inspiracji zmarłego kapłana. W każdym kazaniu takich świadectw jest bardzo dużo, więc tylko dla przykładu: Iaśnie Wieleb. I. Mość X. Woyćiech Tholibowfki [...] Przezacney Kathedrze Poznańfkiey [...] darowat iey Kielich Sczerozłoty, ktory śiedm Tyśięcy waży [...] Dał y Statue śrebrna Woyćiecha S. w cenie Jześćiu Tyśięcy [...] Do 
cudownego Krzyża S. Srebrny Lichtarz o piaći Liliach odkazał (Wier D3v) czy:

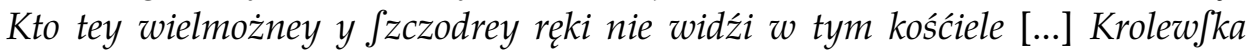
ręka dała, ale ięzyk X. Piotra Skargi uprośił (Birk C3). Natomiast kapłanów, którzy przyczynili się do pomnożenia dóbr kościelnych kaznodzieje nazywają fundatorami (szczodrobliwy fundator, Wier B2).

\section{FASETA III - PRZYMIOTY OSOBISTE}

Jest to, podobnie jak dwie pierwsze, rozbudowany, liczny zbiór atrybutów pokazujący walory charakteru (cnoty) zmarłego kapłana. $\mathrm{Na}$ pierwszy plan wysunięta jest jego dobroczynność i hojność. Na płaszczyźnie leksykalnej są to proste, jednowyrazowe określenia postawy ka-

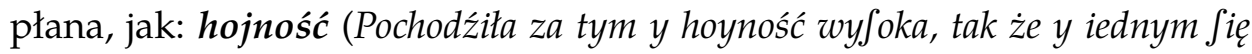
czętokroć rozdźielat z potrzebuiącym talerem. WolsS D3v), szczodrobliwość

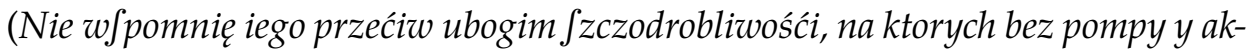
klamacyi, ćicho, przez na」ze ręce, wiemy iak wiele tyśięcy wydał. KochW C2). Częściej jednak ten walor wpisany jest w dłuższy kontekst i o hojności, dobroczynności zmarłego wnioskujemy z opisu działania, jak np.: Przy

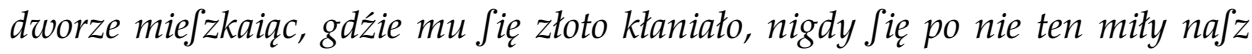

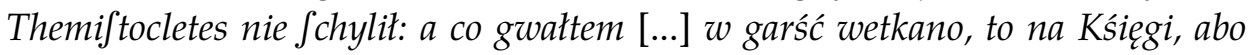

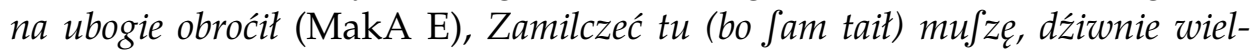

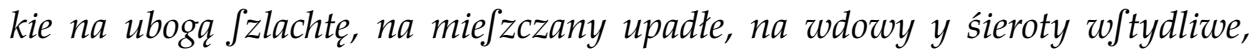
na $\dot{z} y d y, y$ żydowki do wiary nawrocone, iatmużny iego potaiemne (Widz B2). Wysoko ceniona jest skromność kapłana, którą Franciszek Wolsciusz nazywa moderacja i w dalszym wywodzie opisuje jej przejawy: Moderacya Męża tego, wJzytkim była iawna, honorow nigdy nie był ambentem, fawory

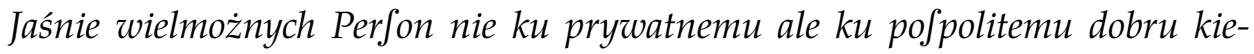

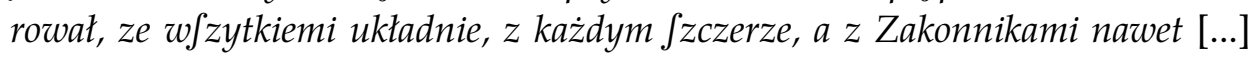
dźiwnie pokornie konwer Jował (WolsS D3). Kaznodzieje przywołują też takie cnoty zmarłego, jak powściągliwość, rozwaga, umiar, współczucie dla bliźnich, życzliwość i inne, np.: Stateczny był iako Bifkup, poważny iako Senator, cnot pełen [...] iako Kapłan święty (Widz [B4v]), Trzezwość, matka wezytkich Cnot [...] ktora w iedzeniu, y napoiu, ba y w Jzatach mierność chowa, taka w nim

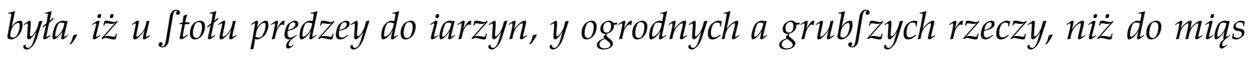
rofkofznych y wydwornych, abo pośćie do ryb korzenno przyprawnych śiagat. Wina barzo Jkromnie, y mało co używat (Widz Cv). Ksiądz Sebastian Stawicki dowodzi cnót zmarłego przez negację cech niepożądanych: nie majz 
tego, coby w mowie nieoftrożność, w konwerfacyey niefzczerość, w Sądach zadać miał niefprawiedliwoość (StawP C3v-[C4]). W innym miejscu, odwołując się do herbu zmarłego, metaforycznie przyrównuje cnoty księdza Samuela Krupki Przecławskiego do liści rozwijających się na gałęzi bluszczu: Do herbownych Zmartego Prałata Liliy, miafto wtafnych przyrodzonych, przyłożyć ia mogé blufzczowe liftki, lubo Godność, Cnota, Mądrość [...] ale w liftkach przeważał fię ku żiemi, bo wielkich przy Dworach przyftug potrzebna poniżoność (StawP [B4v]).

\section{FASETA IV - STOSUNEK DO OBOWIĄZKÓW KAPŁAŃSKICH}

W kazaniach podnoszona jest także kwestia stosunku zmarłego do obowiązków kapłańskich. Pojawiają się w tym kontekście określenia: Pan dobry (Utraćitaś wierna czeladko Pana dobrego. Widz [A3v]), dobry Pasterz (iako dobry Pafterz, te pomięnione Pafterfkiey godnośći [...] exequował funkcye. Wier C3), dobry i czuly Pasterz (Prot ded.), sam spowiedzi stuchat... (Jam Spowiedźi Stuchat, Sam Kathechifmu y paćierza proftaczkow, y wieśniaczkow, choć inni kapłani byli, uczył Sam chrzćit, Sam śluby dawał, Sam infze Kośćielne Sakramenty y obrzędy [...] z wielkim wezytkich podziwieniem, y zbudowaniem odprawował. Widz [C3v]).

Stosunek duchownego do obowiązków kapłańskich, w tym jego postawa wobec wspólnoty wiernych, zawsze był i jest podkreślany i przypominany. Współcześnie wydane Dyrektorium o posłudze i życiu kapłanów tak te zasady formułuje: „Kolejnym przejawem tego, że kapłan jest wobec Kościoła, jest jego rola przewodnika, który prowadzi do świętości wiernych powierzonych jego posłudze, będąca ze swej istoty posługą duszpasterską" (Dyrektorium 2003: 17) czy nieco dalej: „Kapłan jako pasterz wspólnoty jest i żyje dla niej; dla niej modli się, studiuje, pracuje i poświęca się" (Dyrektorium 2003: 56).

\section{FASETA V - WYKSZTAŁCENIE I INTELEKT ZMARŁEGO}

Faseta skupiająca zbiór sądów odnoszących się do wykształcenia i intelektu zmarłego kapłana stanowi novum na tle kazań przygotowanych na pogrzeby osób świeckich. Nie pojawiały się (lub zaledwie incydentalnie) w kazaniach na pogrzebach mężczyzn (Pihan-Kijasowa 2013), a w ka- 
zaniach na pogrzebach kobiet wręcz podkreślano szkodliwość wykształcenia czy nawet generalnie - rozumu (Pihan-Kijasowa 2016). W odniesieniu do kapłanów natomiast wykształcenie, erudycja są pożądane, wręcz konieczne. Kaznodzieje obszernie informują słuchaczy o odbytych przez zmarłego studiach, o szkołach, w których studiował, o efektach tych studiów. I tak np. ksiądz Hieronim Makowski dowodzi, że Jan Adam Komorowski: w Zacney Akademiey Zamoyjkiey fundamenta nauk dobrze założyw zy, wzią Się do Akademiey Krakowjiey, tam w Cnoćie i Naukach znaczny Poftępek uczyniwszy, udał Jie potym do Włofkich Kraiow, do Rzymu, aby tam dofkonaty w naukach y pobożnośći complement uczynit (MakO Cv). W innym miejscu kaznodzieja ten odwołuje się do efektów studiów zmarłego. Pisze: czytay-

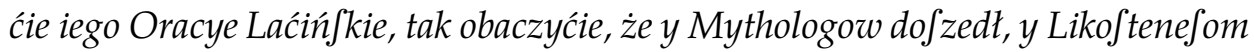

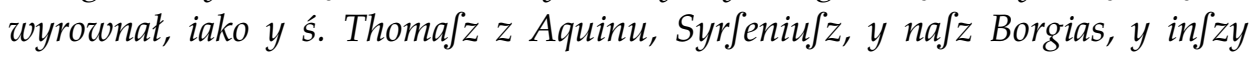
(MakA [C4]). Franciszek Wolsciusz, poświęcając w kazaniu wiele uwagi wykształceniu i mądrości księdza Szymona Starowolskiego, pisał: pioro w ręku, rozum w głowie maiąc peregrynowat: a wjzędźie Bibliothekę znaydwat (WolsS C2) czy Zaprawdę ten uczony Prałat, nigdy fię nafyćić nie mogł tymi erudycyami, ktore tak hoynie excerpowat (WolsS C2v).

Cnota wiedzy i intelektu jest ważną cechą kapłana. Podkreślają to także współczesne zasady, jak np. Dyrektorium o posłudze i życiu kapłanów z 2003 roku dowodzi konieczności formacji intelektualnej: „Duże znaczenie ma studiowanie, pogłębianie i obrona nauki społecznej Kościoła” (Dyrektorium 2003: 78).

Oczywiście argumenty przywoływane w kazaniach można by uszczegóławiać i mnożyć, budować kolejne fasety. Jednak analiza czternastu poddanych oglądowi kazań pokazała, że repertuar środków kształtujących obraz kapłana jest ograniczony i powtarzalny. I choć kaznodzieje dają prawdziwy popis swoich oratorskich możliwości, to jednak odbywa się to na poziomie sposobów dowodzenia retorycznego (Skwara 1999), nie zaś na poziomie profilowania podmiotu. Powtarzalny, schematyczny zestaw faset i wypełniających je argumentów pozwalają, w mojej ocenie, mówić o opisie stereotypowym, mało zindywidualizowanym. Przede wszystkim kapłan jawi się jako osoba pozbawiona jakichkolwiek wad czy ułomności. Najistotniejszym jego atrybutem jest gorąca pobożność, przybierająca niekiedy, w dzisiejszej ocenie, postać dewocyjną. Wyróżnikiem 
kapłana są niematerialne i zwłaszcza materialne zasługi (fundacje) dla Kościoła. Ale też przejawiająca się jałmużnami hojność, szczodrość dla potrzebujących. Kapłan charakteryzuje się licznymi cnotami osobistymi, które czynią z niego postać wyjątkową. No i, w odróżnieniu od osób świeckich, dla których nie było to cechą istotną, atrybutem kapłana jest wykształcenie zdobywane nie tylko w szkołach, akademiach, seminariach krajowych, ale przede wszystkim zagranicznych. Jest więc kapłan dobrze wykształconym erudytą, znającym nie tylko Pismo Święte, ale pisma Ojców Kościoła, autorów starożytnych, dawnych kronikarzy itd. I w kontekście podjętego problemu nie jest ważne, czy tak wyidealizowany obraz kapłana jest tylko kreacją, czy też ma odniesienie do rzeczywistości pozajęzykowej. Natomiast podkreślić należy, że autor kazania jest reprezentantem tego samego środowiska, z którego wywodził się zmarły, wobec tego jego punkt widzenia z pewnością podporządkowany był, rzec można, interesowi środowiska. Ponadto na taki obraz kapłana wpływ miała też sceneria, w której kazanie było głoszone. Kultura chrześcijańska i tradycja wymagały laudacyjnego opisu osoby zmarłej.

Lektura XVII-wiecznych kazań pogrzebowych dowiodła, że ówcześni kaznodzieje, przedstawiając wyidealizowany obraz kapłana, utrwalali stereotyp, który zarysowany już został w pismach wielkich Ojców Kościoła. Spośród nich (a mówimy o Ambrożym, Hieronimie, Augustynie i Grzegorzu Wielkim) szczególną poczytnością przez wiele stuleci cieszyło się dzieło Ambrożego De officiis ministrorum (Obowiazki duchownych) (Święty Ambroży 1967: 13). Znajdziemy w nim wiele wątków, które XVII-wieczni kaznodzieje wykorzystali w procesie kształtowania obrazu kapłana. Kolejne wieki obraz ten uzupełniały i uszczegółowiały.

\section{BIBLIOGRAFIA}

ŹRÓDŁA

Birk - Birkowski Fabin, Na Pogrzebie WIELEBNEGO OYCA X. PIOTRA SKARGI, THEOLOGA Societatis IESU, Wielkiego Kaznodzieie Na Dworze Naia-

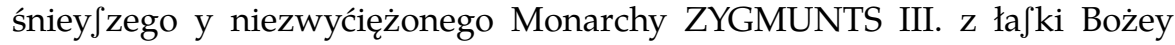
Krola Polfkiego y Szwedzkiego, Wielk. X.Lit. \&.\&. KAZANIE X. FABIANA BIRCOVIUSA W Kośćiele SS. Apoftołow Piotra y Pawła. Roku Panskiego 1612. Septembris 28. W KRAKOWIE, W Drukarni Andrzeia Piotrkowczyka J.K.M. Typographa. Roku Pańskiego 1612.

KochW - O. Aleksander à Jesu [Kochanowski Andrzej], WIZERUNK PASTERZA DOBREGO W Iaśnie Oświeconym Xiążęćiu Iego Mośći X. PIETRZE 


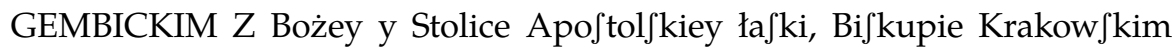
Xiążęćiu Siewierfkim. POKAZANY Przy Exequiach w Kośćiele Oycow Karmelitow Bofsych Swiętego Michała w Krakowie PRZEZ W.O. ALEXANDRA

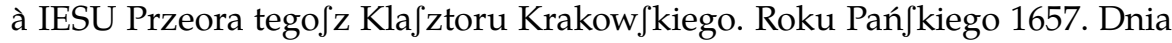
22. Paźdźiernika. W KRAKOWIE, U Wdowy y Dźiedźicow Krzysztofa Schedla J.K.M. Typogr. Roku Pańfkiego 1658.

MakA - Makowski Adam, OBRAZ WIELEBNEGO OYCA FABIANA BIRKOWSKIEGO Z Zakonu Dominika świętego DOKTORA WYSTAWIONY Na Kazaniu Pogrzebnym, Przez X. ADAMA MAKOWSKIEGO SOCIETATIS IESU, W KRAKOWIE W Kośćiele Troyce Swiętey, Dnia 10. Grudnia. Roku 1636. Za dozwoleniem Starfzych, y Urzędu Duchownego. W Druk. Andrz. Piotrkowczyka, Typogr. K.I.M.

MakO - Makowski Hieronim, KAZANIE POGRZEBNE, OFIARA ODDANA NA DWOCH GORACH WYDATNYCH, WYSTAWIONA NA POGRZEBIE PRZEWIELEBNEGO I.M.X. IANA ADAMA KOMOROWSKIEGO, OPATA WĄCHOCKIEGO, KANONIKA KRAKOWSKIEGO, I.K.M. Sekretarza, Regenta Kancellariey Koronney, \&c. W Kośćiele Zamoyskim, Przez Wielebnego Oyca HIRONYMA MAKOWSKIEGO, Pifma S. Doktora, Kazno-

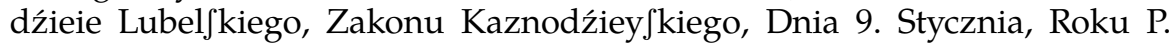
1648.

Mros - Mroskowski Marinus, KAZANIE na Dźień Pogrzebu Jasnie Oswieconego Iego Mosci X. PIOTRA GEMBICKIEGO Biskupa Krakowskiego, Xiążęćia SiewierJkiego, Miane. PRZEZ X. MARINUSA MROSKOWSKIEGO

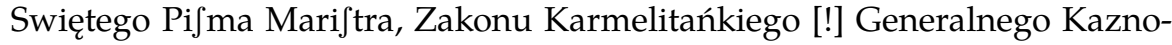
dźieie, w Kośćiele Farnym Krakowskim Panny Maryey, na wynieśieniu ćiała. Dnia 18. Paźdźiernika Roku 1657. W KRAKOWIE U Wdowy y Dźiedźicow Franciffka Cezarego I.K.M. Typog.

OlszB - Olszewski Jakub, KAZANIE Na Pogrzebie Wielebnego w Bogu Prałata. I.M.X. KAROLA IANA BIAŁOZORA PROBOSZCZA WILENSKIEGO REFERENDARZA W.X.LITH. Y KANCELLARIEY MNIEYSZEY LITH. REGENTA. Miane w Kośćiele Kathedralnym Wileńfkiem 13. dnia Czerwca. Roku Pańfkiego 1631. Przez X. IAKUBA OLSZEWSKIEGO Theologiey S. Doktora, Philofophiey Dźiekana, y w Kośćiele Farskiem Wileńskiem S. IANA. Societatis IESU Kaznodźieię. W Drukarni Akademiey Societatis IESU. Roku Pańfkiego 1631.

OlszW - Olszewski Jakub, KAZANIE Na Pogrzebie Prześwietnego y Przewielebnego w Chriftuśie. Oyca y Pana. I.M.X. EUSTACHEGO WOŁOWICZA BISKUPA WILENSKIEGO. PRIMASA W.X.LITEWS. Miabe w Kośćiele Kathedralnym Wileńfkim. 7. dnia Lutego. Roku Pańfkiego 1630. Przez X. IAKUBA

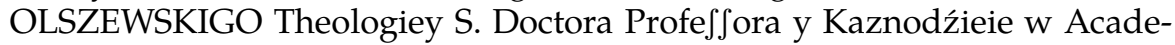
miey Wileńskiey Societatis IEU. W Drukarniey Academiey Societatis IESY Roku 1630.

PigK - Pigłowski Wojciech, KAZANIE Na Pogrzebie Ieo Mośći Xiędza ZYGMUNTA CIELECKIEGO, PROBOSZCZA POZNAŃSKIEGO, Gnieźnień- 
skiego, Krakowskiego, Płockiego, KANONIKA. Miane w Poznaniu w Kośćiele Kathedralnym, Przez I. Mći. X. Woyciecha Pigłowskiego Kanonika Poznańskiego etc. etc. A do druku podane przez W. Xa. Mattheusza Zgierskiego, Poddziekaniego Kośćioła Kathedralnego Poznańskiego, W Roku Pańskim 1652. dnia 10. Grudnia W POZNANIU, W Drukarni Wdowy y Dziedzicow Woyćiecha Regulusa

Prot - Protfic Marcin, POŁOW GORNOLOTNEGO IASTRZĘBCA Iaśnie Wielmożnego Mośći X. STANISŁAWA SARNOWSKIEGO BISKUPA KUIAWSKIEGO i POMORZKIEGO, w Dźień Pogrzebu, W Kośćiele Katedralnym Włocławskim, Przez X. MARCINA PROTFICA S.T.D. Kanonika i Kaznodźieię Katedralnego Włocławskiego. Anno 1681. Die 27 Januarij Pokazany. z Dozwoleniem Starfzych. W POZNAIU w Drukarni I.K.M. Cllegium Societatis IESU.

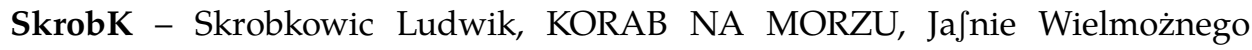
godney pamięći Iego Mći X. IAKUBA ZADZIKA, BISKUPA KRAKOWSKIEGO, Xiążęćia Siewier אkiego, \&. Pokazany z Ambony W Kośćiele świę-

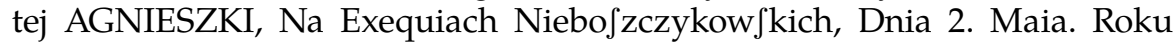
1642. Przez LUDWIKA SKROBKOWICA, Zakonu Braćiey Mniey〕zey de Objeruantia. A potym w druk podany $Z$ rofkazania, y za dozwoleniem Starfzych. W KRKOWIE, W Drukrniey Andrzeia Piotrkowczyka, Typographa I.K.M. [bernardyn]

StawP - StawickiSebastian, PRAŁAT LILIOWY, W Szlacheckiey Familiey zaJadzony Ogrodźie, W Kośćielney Godnośći rozkwitły Wirydarzu, W Cnotach Pobożnośći, Sławie, y w Lećiech doyrzały. Boskiemi Urwany Rękoma PRZEZ SMIERC Swietnie Wielebnego Iego Mośći Xiędza SAMUELA KRUPKĘ PRZECŁAWSKIGO. I.K.M. Sekretarza, Gnieźnieńskiego y Pułtowskigo Kanonika, Dźiekana Łowickiego, Kantora Sandomierfkiego. Na Pogrzebowym Akćie do wieczney \ławy wonnośći KAZANIEM PODANY. Przez X. SEBESTIANA STAWICKIEGO, Zakonu S. Pawła Pierwzego Puftelnika, Theologa y Kazodźieię. W Kośćiele Farnym KoniuJkim, R.P. 1659.

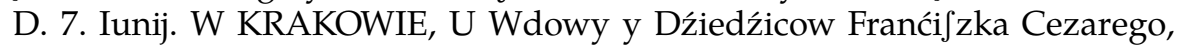
I.K.M. Typog. Roku Pańskigo, M.DC.LX.

Widz - Widziewicz Marcin, KAZANIE Na Pogrzebie Prześwietnego y Przewielebnego w Chryftuśie Oyva y Pana. BENEDIKTA WOYNY BISKUPA WILENSKIEGO PRIMASA W.X. LITEWSK. Miane w Kośćiele Kathedralnym Wielńfkim 1. dnia Marca, Roku Pańfkiego 1616. Przez X. MARCINA WIDZIEWICZA Theologa Sicietatis IESU. W WILNIE, W Drukarni Leona Mamonicza.

Wier - Wierusz Franciszek, NAŁĘCZ PASTERSKIEY GODNOŚĆI JASNIE WIELMOZNEGO IEGO MOŚĆI X. WOYCIECHA THOLIBOWSKIEGO BISKUPA POZNANSKIEGO, Dźielną mężny śmierći ręką rozwiązany: Od Oblubie-

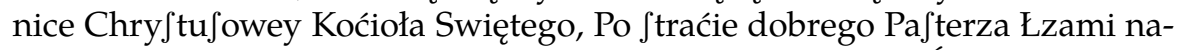

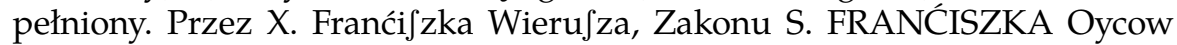
Reformatow Prowincyey Wielgo-Polskiey, Kaznodźieię Kathedralnego Po- 
znańskiego, Przy wyprowadzęniu ćiała: z Kapelle KAZIMIERZA S tychże Oycow, Troiftym cnot świętych utwierdzony Węzłem Roku Pańskiego, 1663, Dnia 13. Sierpnia, w Poznaniu. Drukowano w Poznaniu u Dźiedźicow Woyćiecha Regulusa.

WolsS - Wolsciusz Franciszek, SUPLEMENT FUNERALNEGO APPARATU Dla

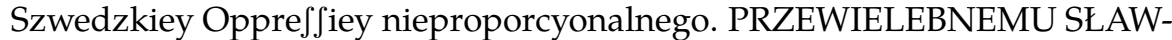
NEY PAMIĘCI IEGO MOSCI X. SZYMONOWI STAROWOLSKIEMU, Kanonikowi Kathedralnemu Krakowfkiemu, Kantorowi Tarnowfkiemu, \&c.

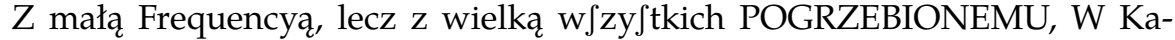
thedralnym Kośćiele Krakowfkim, Anno 1656, Die 6. Aprilis. Przy ktorym AKCIE zaniechaną Apparencyą Supplementował, KAZANIEM POGRZEBNEM, X. FRANCISZEK VOLSCIUS, Kaznodźieia Zakonu Braćiey Mniey fzych Swiętego FRANCISZKA Reformatow. W KRAKOWIE, U Wdo-

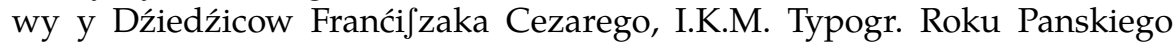
1658.

\section{LITERATURA PRZEDMIOTU}

Bartmiński J., Niebrzegowska S., 1998, Profile a podmiotowa interpretacja świata, w: Profilowanie w języku $i$ w tekście, red. J. Bartmiński, R. Tokarski, Lublin, s. 211-224.

Dyrektorium 2003: Dyrektorium o posłudze i życiu kapłanów, 2003, Poznań (wydane przez Kongregację ds. Duchowieństwa).

Dziechcińska H., 1990, Panegiryk, w: Słownik literatury staropolskiej, red. T. Michałowska, B. Otwinowska, E. Sarnowska-Temeriusz, Wrocław-Warszawa-Kraków, s. 544-547.

Michałowska T., 1990, Literatura okolicznościowa, w: Słownik literatury staropolskiej, red. T. Michałowska, B. Otwinowska, E. Sarnowska-Temeriusz, Wrocław-Warszawa-Kraków, 420-424.

Otwinowska B., 1990, Retoryka, w: Słownik literatury staropolskiej, red. T. Michałowska, B. Otwinowska, E. Sarnowska-Temeriusz, Wrocław-Warszawa-Kraków, s. 714-720.

Pihan-Kijasowa A., 2013, Kreacja pochwaty w barokowych kazaniach pogrzebowych, w: Cum reverentia, gratia, amicitia... Ksiega jubileuszowa dedykowana Profesorowi Bogdanowi Walczakowi, red. J. Migdał, A. Piotrowska-Wojaczyk, Poznań, s. 615-628.

Pihan-Kijasowa A., 2016, Językowe i kulturowe komponenty pochwały w XVII-wiecznych kazaniach na pogrzebach kobiet, w: Święte księgi judaizmu, chrześcijaństwa $i$ islamu w słowiańskim kręgu kulturowym, t. 3: Słowiańscy chrześcijanie Wschodu i Zachodu. Język - Dialekt - Piśmiennictwo, red. M. Krajewska, J. Kulwicka-Kamińska, A. Szulc, Toruń, s. 119-146.

Skwara M., 1999, O dowodzeniu retorycznym w polskich drukowanych oracjach pogrzebowych XVII wieku, Szczecin.

Skwara M., 2008, Jana Zygrowiusza "Melius..." na tle polskich drukowanych oracji pogrzebowych XVII wieku zwiazanych z Radziwiłłami. Wraz z tekstem kazania 
Melius albo kazanie na wyprowadzenie ciała Jaśnie Oświeconego (...) Pana Janusza Radziwitła..., Szczecin.

Skwara M., 2009, Polskie drukowane oracje pogrzebowe XVII wieku. Bibliografia, Gdańsk.

Sokołowska J., 1990, Barok, w: Słownik literatury staropolskiej, red. T. Michałowska, B. Otwinowska, E. Sarnowska-Temeriusz, Wrocław-Warszawa-Kraków, s. $72-82$.

Szostek T., 1990, Kazanie, w: Słownik literatury staropolskiej, red. T. Michałowska, B. Otwinowska, E. Sarnowska-Temeriusz, Wrocław-Warszawa-Kraków, s. 317-321.

Święty Ambroży z Mediolanu, 1967, Obowiązki duchownych, Z oryginału łacińskiego przełożył K. Abgarowicz, przekład przejrzeli J. Sajdak i J. Wikarjak, Warszawa.

Topolska M. B, 1984, Czytelnik i książka w Wielkim Księstwie Litewskim w okresie Renesansu i Baroku, Wrocław.

Wierzbicka A., 1993, Nazwy zwierząt, w: O definicjach i definiowaniu, red. J. Bartmiński, R. Tokarski, Lublin, s. 252-267.

Wojtak M., 1999, Modlitwa ustalona - podstawowe wyznaczniki gatunku, w: W zwierciadle języka $i$ kultury, red. J. Adamowski, S. Niebrzegowska, Lublin, s. $129-138$.

Wojtak M., 2004-2005, Genologia tekstów użytkowych, „Postscriptum” 2004-2 2005-1 (48-49), s. 156-171.

\title{
STEREOTYPE OF A PRIEST BUILT INTO $17^{\text {th }}$ CENTURY FUNERAL SERMONS
}

\begin{abstract}
17th century funeral sermons, a set of approximately 600 texts, structured following the antic rhetoric principles, modified in modern times, are a genre of panegyric literature, praising the deceased. Among preserved prints, sermons prepared on the occasion of funerals of the clergy constitute a large collection. Their structure, although basically convergent with the principles of laudation applicable to that type of expression, shows certain differences on the level of the degree of a realisation of its individual elements. The element which depicts the time preceding the birth of the clergyman and arguments referring to his lineage are eliminated or significantly reduced. On the other hand, emphasis is put on all aspects which show the piety of the deceased priest, his merits for the Church, relationship towards the faithful under his care. The image of the clergy presented in the sermons is poorly individualised, in fact, it could even be referred to as a stereotypical one.
\end{abstract}

Key words: 17th century funeral sermons, panegyric literature, image of a priest, stereotype 